\title{
Estética e filosofia das artes musicais africanas na perspectiva da educação musical na América Latina
}

Aesthetics and philosophy of African musical arts in the perspective of music education in Latin America

Katharina Döring*

UNEB - DEDCI

Katharina.doring@gmail.com

*Graduação em Educação Musical (2000) e mestrado em Etnomusicologia (2002) pela Universidade Federal da Bahia; doutorado em Educação (2011) com ênfase em Arte-Educação pela Universidade Siegen - programa INEDD. Desde 2002 professora assistente da Universidade do Estado da Bahia (UNEB).

Submetido em 06/04/2018, Aprovado em 20/11/2018 


\section{Resumo}

O presente artigo apresenta um diálogo com autores/as do chamado Atlântico Negro para introduzir no debate necessário sobre uma educação musical embasada nos saberes e bases filosóficas - históricos e contemporâneos - das artes musicais africanas e da diáspora africana. Aponta uma lacuna histórica nos estudos das musicalidades afro-latinas, afro-caribenhas e afro-americanas nos países da América Latina, assim como a necessidade de construir procedimentos e fundamentos metodológicos aplicados ao ensino das artes musicais (das diásporas) africanas com ênfase no contexto brasileiro. A autora procura incentivar um debate epistemológico, referenciado por vários autores dos contextos musicais e históricos da África e da Diáspora africana, e esboçar um arcabouço teórico para uma educação musical nas bases das matrizes africanas nos demais países e regiões com expressões culturais e musicais negras, que possa levar a uma educação e formação musical e performática (das diásporas) africanas.

Palavras-chave: Educação musical na diáspora africana; Estudos das músicas negras nas Américas; epistemologias das artes musicais (das diásporas) africanas

\section{Abstract}

This article presents a dialogue with authors of the so called Black Atlantic to introduce the necessary debate about a musical education based on the philosophical and historical knowledge and bases - historical and contemporary - of the African musical arts and the African diaspora. It points to a historical gap in the studies of Afro-Latin, Afro-Caribbean and African-American music in Latin American countries, as well as the need to build procedures and methodological foundations applied to the teaching of African (diaspora) musical arts with emphasis on the Brazilian context. The author seeks to encourage an epistemological debate, referenced by various authors from the musical and historical contexts of Africa and the African Diaspora, and to outline a theoretical framework for music education on the bases of African matrices for the most of countries and regions with black cultural and musical expressions, that in future may lead to African (African diaspora) musical and performance education and training.

Keywords: Musical education in the African diaspora; Studies of black music in the Americas; epistemologies of the African (diaspora) musical arts 


\section{Relações étnico-raciais na Música: para um campo de estudos das artes musicais na diáspora africana}

O presente artigo se empenha em mediar uma compreensão sobre os fundamentos das musicalidades negras desde as artes musicais e performáticas africanas e seus princípios sonoros, est/éticos e filosóficos, sendo praticadas pelos mais diversos povos e culturas africanos em liberdade, até as músicas e danças da diáspora africana que foram marcadas pela travessia transatlântica cruel, enquanto cantos, toques, poéticas e expressões corporais em permanente estado de luto e luta pela liberdade e pelo reconhecimento.

Ciente da generalização tamanha, não posso contemplar a imensidão das artes musicais africanas de cada região, povo e contexto contemporâneo dos países africanos e da diáspora africana, por se tratar de uma conversa inicial e introdutória, apontando somente algumas pistas de leituras, debates e epistemologias para a compreensão das mesmas. Procuro esboçar um arcabouço teórico e um debate para uma educação musical nas bases das matrizes africanas, que possa levar a uma formação musical e performática afro-latina: não somente diversa, social e inclusiva, mas transformada e diferenciada! Sinalizo a necessidade de criar uma estrutura curricular e epistemológica para a formação e profissionalização musical para aqueles que em performance, composição, pesquisa, execução e sobretudo na pedagogia musical querem trabalhar com repertórios e concepções metodológicas que se baseiam nas especificidades e necessidades das artes musicais (das diásporas) africanas.

Um adendo necessário: trago o foco para músicas do chamado complexo Atlântico Negro': uma abrangência histórica e geo-cultural transatlântica que forma o triângulo de trocas culturais entre África, América e Europa. Utilizo o termo 'artes musicais africanas' (por extensão da diáspora africana)', empregado pelo compositor sul-africano Meki Nzewi (2005, 2007), que compreende o fazer musical em conjunto com as expressões poéticas e cênicas, embasadas na filosofia, história oral e espiritualidade africanas. Nzewi e outros autores apresentam uma visão integrada sobre os saberes e fazeres musicais africanos que envolvem praticamente sempre a expressão corporal, ritual e gestual - movimentos, performances e danças - a qual neste artigo não posso aprofundar explicitamente, mas a compreendo e incluo como elemento integrado e implícito. Acrescento que na cultura e música afro-latina, em nenhum momento penso na exclusão ou separação das bases musicais europeias e indígenas, que formam em conjunto as demais tradições, narrativas e práticas cênico-poético-musicais nos demais países da América Latina.

Em alguns países e regiões encontram-se as presenças e estéticas indígenas mais marcantes e resistentes (Peru, Bolívia, Equador...); em outros imigrantes europeus deixaram suas culturas musicais populares como marca predominante (Argentina, Brasil em parte...); em Cuba, Brasil, Suriname, Haiti, Jamaica etc., se sobressaíram inúmeros 
gêneros musicais com bases musicais, estéticas e comportamentais africanas. Em outras regiões surgiram tradições cênico-poético-musicais que reúnem elementos das três culturas musicais, tornando desnecessário uma subdivisão em partes originárias porque geraram novas identidades culturais e estéticas (Brasil, México, Colômbia,...). Portanto, aqui não posso aprofundar os fundamentos musicais indígenas e das culturas europeias populares, e tampouco os aspectos cênicos e poéticos específicos: trago a ênfase para as bases filosóficas e estéticas das artes musicais africanas, por reconhecer a necessidade de atender a uma nova geração:

A jovem geração de afrodescendentes politicamente mobilizados precisa pressionar os responsáveis por seu pais para que a África continental e a África da diáspora sejam ensinadas na escola em pé de igualdade com as demais culturas que contribuíram na formação do povo brasileiro. Vozes internas e externas da comunidade afrodescendente do Brasil insistem na necessidade de uma reciclagem, e uma nova abordagem epistemológica da África que rompa com as ideias preconceituosas da herança intelectual colonialista. (MUNANGA, 1996, p. $23 \mathrm{em}$ LARKIN, 2008)

Embora seja particularmente urgente no contexto da diáspora afro-latina de debater "uma nova abordagem epistemológica da África", formulado por Munanga há 22 anos atrás (!), podemos constatar de que a dificuldade de transformar as concepções curriculares na educação e formação musical, não se encontra somente na diáspora africana, e sim, nos países africanos também, devido ao processo de colonização nos demais países africanos, onde a educação escolar e universitária foi implantada a partir da visão humanista ocidental e consequentemente na formação musical também:

Devemos ser corajosos em reconhecer isso e começar a defender a criação de categorias separadas para incorporar os "arquivos vivos" dos sistemas de conhecimento indígenas, que também refletem a aculturação e a diáspora africana. Embora exista uma grande necessidade, especialmente na África, de produzir pesquisas "clássicas" de acordo com os procedimentos padronizados do Ocidente, os formuladores de políticas, quando chegam às artes performáticas, fecham os olhos para a natureza oral que forma uma parte intrínseca dos sistemas de conhecimento indígenas. em geral e práticas de artes musicais especificamente. Ao ignorar a natureza baseada no desempenho das artes musicais na África, estamos comprometendo um aspecto muito singular da filosofia de seus povos, explicitada na interação diária com os sistemas de conhecimento indígenas. Há um grave perigo de que possamos acabar como espectadores de uma joia que está morrendo, praticando a mais extrema forma de colonialismo, tratando as artes musicais como artefatos de museu a serem estudados em circunstâncias de laboratório. (HERBST, 2005, p. 16 - nota de rodapé) ${ }^{2}$ 
Herbst alerta para o perigo de perder os saberes 'indígenas' tradicionais dos povos africanos, os "arquivos vivos", pelo fato de que durante décadas, a formação eurocêntrica nas artes, contribuiu para que algumas gerações fechassem os olhos perante a riqueza musical, estética e filosófica ancestral, sendo tratada como "folclore". Essa 'cegueira', ou melhor 'surdez', em não reconhecer as bases performáticas e da oralidade nos saberes dos povos tradicionais africanos, se repete na América Latina, onde geralmente, poucos elementos reconhecidos pelo ouvido europeizado são 'aproveitados'. Retrata a situação histórica no Brasil, que extrai das culturas negras, o que lhe for conveniente, descartando o resto: as pessoas, seus saberes profundos e contextos sociais, históricos e culturais, gerando muitas vezes uma imagem e sonoridade deturpada e estereotipada.

$\mathrm{Na}$ formação musical pouco se estuda e dialoga com a literatura das ciências sociais e históricas, referente às culturas e músicas da diáspora africana, porque sua base musical eurocêntrica, mesmo quando bem-intencionada, não consegue compreender as concepções musicais africanas e da diáspora africana, por perder na tradução das mesmas, a maioria dos elementos indispensáveis para sua execução e recepção na complexidade e integridade. As ciências sociais por sua vez, geralmente não tem como foco, interpretar e analisar as especificidades das expressões musicais que requerem noções teóricos de música elementar e sobretudo de fundamentos teórico-práticos das músicas negras, sejam africanas, da diáspora africana, ou mesmo do jazz norte-americano. Portanto, torna-se necessário introduzir estudos musicológicos culturais, assim como as próprias práticas musicais de matrizes africanas na educação musical, para poder compreender e conceituar as teorias e formas de transmissão de saberes nesse contexto específico:

\begin{abstract}
A produção de conhecimentos específicos sobre as práticas musicais negras é central para avançar na construção desses marcos de conceitualização. Ao mesmo tempo precisamos avançar na analise das consequências epistemológicas da colonialidade, dando conta da inadequação das ferramentas conceituais criadas para o estudo da cultura dos setores dominantes quando aplicadas ao estudo da cultura dos setores populares, especialmente tratando-se de músicas de matrizes africanas. $O$ que precisamos é construir ferramentas conceituais a partir dessas mesmas práticas musicais e da sensibilidade que elas implicam, bem como dos processos das nossas práticas intelectuais e acadêmicas em estuda-las. (MAKL, 2011, p. 58) (grifo meu)
\end{abstract}

Para compreender o pensamento complexo sobre performance, pesquisa e educação musical, numa visão transdisciplinar e transcultural, torna-se necessário desconstruir alguns valores e conceitos 'universalistas' que ha décadas se perpetuam nos centros universitários de formação musical no Brasil, com pouca revisão e mudança de paradigmas significativas. Em primeiro lugar, compreendo como imprescindível redefinir a concepção sobre música em geral, partindo do 'Sistema Único de Música' (SUM), tido como exclusivamente de domínio ocidental, sinônimo de música clássica central-europeia. Surge então a pergunta, do porque desse pressuposto hierárquico, a qual não vale somente para a diáspora africana e o contexto colonial: ignorar todas as possíveis formas, teorias, concepções e práticas musicais no mundo (asiáticas, indígenas, 
africanas, oceânicas e mesmo europeias de tradição oral, populares, etc.), implica na hegemonia ocidental exclusiva quase nunca questionada sobre teorias e fundamentos musicais, no que se refere a certas leis de harmonia, melodia, ritmo, afinação, organologia, técnicas vocais, formas de composição e execução, mas também a atitudes e comportamentos socioculturais e estéticas que são assumidos na execução, performance musical e à recepção e participação dos praticantes e do público.

Um dos questionamentos seria como situar o complexo das músicas negras: seria música africana e música da diáspora africana, uma música feita por qualquer um que a produz a partir das bases filosóficas das artes musicais africanas? A compreensão sobre a africanidade ou não de um estilo ou comportamento musical estaria provavelmente na definição que se tem sobre culturas e músicas africanas, e sobre o que seria a música dos povos afrodescendentes na América Latina, nos Estados Unidos e na Europa, porque na maioria das vezes, essa definição tem muito mais a ver com a percepção, geralmente colonizada, sobre o que caracterizaria as músicas (de matrizes) africanas.

A visão hegemônica do hemisfério norte alimentou no Brasil e na América Latina em geral, uma imagem folclorizada, estereotipada e geralmente racista sobre as artes musicais africanas e da diáspora africana, a qual espelha o contexto histórico da colonização e escravatura, quando africanos e seus descendentes criaram e reproduziram suas formas musicais numa situação extrema de perseguição e repressão. Em toda diáspora africana, eles encontraram 'soluções' e criações musicais em resposta à sua condição de escravizado e aprisionamento que esboço aqui obviamente em linhas muito gerais:

Primeiro, como resistência aberta ou camuflada (capoeira, reggae, rap entre muitos outros); Segundo, como tentativa de preservar sua origem, idealizando e perpetuando uma tradição 'inventada', porém ancestral, a partir de um imaginário mais ou menos preservado, ou mesmo congelado (p. ex. alguns aspectos das religiões de matrizes africanas);

Terceiro, como possibilidade de se inserir na cultura hegemônica mediante concessões estéticas e comportamentais, inserindo-se em formas e eventos musicais euro-descendentes, os quais muitas vezes se africanizaram por sua vez, p. ex. o carnaval. Em seguida um exemplo sobre essa disputa do espaço e da identidade, onde as autoridades da elite branca procuravam reprimir e proibir as manifestações negras para não perturbar 'seu carnaval civilizado e apartado', tanto no Brasil, como em Cuba, na virada do sec. XIX para o sec. XX, o que mostra a profunda negação das tradições negras da diáspora africana, de acordo com Reid, que retratou a história das culturas negras na América Latina:

Estas manifestações "civilizadas" do carnaval dominavam as reportagens dos jornais sobre o evento anual, mas essa cobertura ao mesmo tempo revelava a presença continuada das comemorações de rua dos negros. 'Se alguém de fora julgar a Bahia pelo seu Carnaval'; queixou-se um jornal de Salvador em 1903, 'não pode deixar de colocá-la a par da África:' Quando o chefe de polícia da cidade começou a reprimir severamente os batuques negros em 1904 e finalmente os proibiu completamente no ano seguinte, o alívio da elite baiana era palpável: „Embora não houvesse desaparecido de todo a péssima exibição dos batuques africanizados, em todo o caso diminuíram muito. (...) Ninguém tem o direito de 
descreditar o meio em que vive, revivendo costumes africanos. (...)

As elites cubanas foram igualmente veementes em sua condenação do carnaval afro-cubano: "Todo ano, durante o Carnaval, testemunhamos cenas que desonram a nossa cultura e que fazem-nos supor que uma parte da nossa população ainda seja influenciada por atavismos que entram em conflito com a civilização. O espetáculo é (...) repugnante: homens e mulheres, sem o menor senso de vergonha, desfilando tumultuosamente pelas ruas ao som de música africana, cantando coros monótonos e reproduzindo em seus movimentos gestos que podem ser apropriados na África selvagem, mas que não têm sentido na Cuba civilizada." (REID, 2007, p. 158)

Sabemos como terminou essa batalha pelo domínio do território carnavalesco: os carnavais são basicamente afro-latinas em suas estéticas performáticas, musicais e comportamentais, porém, o domínio e aproveitamento político-econômico, em geral continua atrelado a corporações e instituições da elite! Quarto caminho, popularizado por toda América Latina, foi a camuflagem como folclore, sendo tolerado enquanto tempo e espaço 'lúdico', (infantilizado) que foi permitido aos escravizados de forma condescendente. Este último caso, considero especialmente problemático, porque exemplifica o racismo brasileiro 'bem-intencionado' (também presente entre músicos e professores de música), que não se enxerga, mantendo uma atitude hipócrita e condescendente, mesmo em assuntos da culturas e músicas negras, que não lhe condizem, sem, no entanto, oficialmente reconhecer saberes, fundamentos teórico-filosóficos das pessoas e experiências negras nas instituições.

O campo da música necessita de aprofundar os estudos culturais, as relações étnico-raciais, e as epistemologias e bases filosóficas africanas, segundo o filósofo e educador Eduardo Oliveira que aprofunda a crítica cultural e estética:

O conceito de representação, identidade, sujeito, subjetividade, objetividade, apesar de serem largamente analisados e ressemantizados, quando não descartados, ainda preservam sua forma cultural helênico-cristã. O que entendemos por forma cultural não é, obviamente, o conteúdo de um discurso ou narrativa, tampouco suas regras de sintaxe ou de semântica. Forma cultural, aqui, diz respeito ao escopo cultural presente em qualquer narrativa e espaço passível de lhe dar as condições de produção de seu sentido territorializado. É o contexto investido de sentido. Sentido produzido na tradição do lugar e que, como já foi largamente demonstrado, de modo peculiar, por autores como Foucault (1996) e Geertz (1989), muda de acordo com o tempo e o espaço. É um sentido que resulta em processos múltiplos de significação. Significações frutos de tensões entre interpretações várias, interessadas em disputas pelo real. Real, por sua vez, resultado desses fluxos de informação e poder que alteram os padrões econômicos e políticos de uma dada comunidade, ou mesmo de uma sociedade inteira. A Forma Cultural, no entanto, não é uma estrutura, apenas. Ela é a possibilidade da própria estrutura. (...) (OLIVEIRA, 2012, p. 34-35)

Um dos desafios decoloniais da diáspora africana, p. ex. no campo da cultura, das artes e músicas, seria de desmontar o racismo e pensamento colonizador subjacentes que marca as experiências e músicas da diáspora africana por séculos em suas negociações e adaptações culturais, estéticas, espirituais entre outros. $O$ jeito brasileiro de se adaptar e de adaptar suas expressões musicais, tornaram mais difícil a possibilidade 
de transformar essa 'estrutura' da 'Forma Cultural', e suas bases e pressupostos, porque em geral, não assumem um posicionamento est/ético muito bem definido, com isso deixando a margem para o implícito: a Forma Cultural embranquecida, mesmo em contextos negros. Este argumento reforça a necessidade de conhecer as epistemologias das músicas e estéticas negras, as quais não precisam competir com as bases europeias, nem contesta-las!

Surge então a indagação, se na América Latina haveria um corpo musical teórico, prático e consagrado que sustenta a experiência histórica dos povos e das músicas da diáspora africana (que carregam também as marcas e os traços dos povos indígenas e europeus), e quais seriam os "conceitos, significados, teorias e valores africanos da educação e prática das artes musicais", segundo Nzewi e como podemos "construir ferramentas conceituais a partir dessas mesmas práticas musicais e da sensibilidade que elas implicam", formulado por Makl?

No Brasil, como em outros países da América Latina, há uma longa história de negação dessas criações ou de diminui-las com a ideia da mestiçagem 'para melhorar', no sentido explícito ou implícito do branqueamento e um 'luso-tropicalismo' antropofágico:

Em nosso pais, o modelo hegemônico de cultura se baseia numa concepção que não rejeitou a contribuição dos negros africanos, mas os colocou em uma posição ingênua e secundaria, além de infantiliza-los (Sodré, 2000). O padrão utilizado se baseou na cultura ibérica, que foi, posteriormente, acrescida dos elementos africanos e indígenas, dando origem ao modelo "luso-tropicalista" (Freyre, 1975) da cultura brasileira. (BARATA, 2011, p. 30)

Por outro lado, a força das artes musicais africanas parece se sobrepor nos países com população negra expressiva e gerar comportamentos musicais e performáticos que deixaram de se definir pela sua parcela europeia, sendo internacionalmente reconhecido como afro-americanos, afro-brasileiras, afro-caribenhos, afro-latinos e tendo transformada a história da música popular internacional. Portanto, surge a questão, porque música africana, jazz, música afro-latina, não poderiam postular universalidade e gerar uma 'Forma' e portanto, formação musical própria? Porque não poderia servir e ser acessível a toda população do mundo, no que diz respeito a educação e formação musical? Porque seria prioritariamente a música europeia, embora as formas musicais afro-populares estão sendo veiculadas nas demais mídias convencionais e digitais? Porque teriam que estar sempre em categorias, antigamente: exóticas e folclóricas, hoje: world music e patrimônio imaterial, ou então fora do 'padrão', marginalizado enquanto subcategoria, só para 'especialistas'? - novamente ouvindo Oliveira:

Não se trata, portanto, da crítica conceitual a conceitos consagrados pela tradição do pensamento ocidental. Trata-se de combater, isso sim, a condição mesma de produzir tais conceitos, sua produção elevada a esse grau de abstração para que, efetivamente, a crítica não se reduza ao aspecto conceitual, mas reincida sobre a atitude que o produziu. É a interface texto e contexto. Trata-se de considerar a "lógica" própria do Outro, sem reduzir o Outro à fórmula do Mesmo. Não basta ouvir sua voz e respeitar seu discurso. É preciso estar aquém, isto é, considerar as próprias condições do discurso a ser efetivado. Fazê-lo, entretanto, apresenta-se como uma dificuldade extrema. (OLIVEIRA, 2012, p. 35) 
Oliveira aponta para o cerne do debate que parece girar em torno de si, porque "Trata-se de considerar a 'lógica' própria do Outro, sem reduzir o Outro à fórmula do Mesmo", ou seja: a redução, a condescendência de querer definir o Outro pela lente e 'fórmula' ocidental e colonizada, contribui para que as pessoas e suas narrativas e expressões musicais e performáticas não sejam percebidas e ouvidas adequadamente. Enquanto isso, o etos da concepção musical africana, coloca o ser humano e sua interação social, no centro do fazer musical, de acordo com o etnomusicólogo ganense Kofi Agawu:

A música, entendida num sentido africano expandido como algo parecido com uma obra de arte total (Gesamtkunstwerk), é feita por relembrar e sustentar canções, no ato de bater tambores, castanholas e cabaças, e negociar movimentos. Embora existam atos individuais que possam sugerir a criação individual de música, a maior parte da criação de música entre os Ewe do Norte, é concebida em relação a outros atores humanos. Como o derramamento de libação, a realização de notícias ou a encenação de narrativas enganosas, a música é uma atividade completamente comunitária. (AGAWU, 2007, p. 7)³

O princípio da 'arte total', envolvendo narrativas, sonoridades, performances e interações sociais, sempre dialogando e se conectando diretamente com a comunidade presente, representa possivelmente uma das essências do fazer musical africano e da diáspora africana. O conceito musikmaking de Agawu, identificado como atividade social e comunitária no contexto africano, se preservou nas práticas musicais do complexo Atlântico Negro, sendo também observada e desenvolvido por Christopher Small (1987/1998), levando ao conceito do musicking, inspirado nas musicalidades negras norte-americanas: perseguidas e rejeitadas - as vozes, sonoridades, danças e gestos, mediante rituais e ritmos do tronco africano - formam o eixo central da música social nas comunidades negras. A performance negra cênico-poético-musical transcende o substantivo 'música', e pode ser melhor compreendido com a definição do musicking, enquanto verbo e ação:

A natureza e o significado fundamental de música não está nos objetos, nem mesmo nas obras/composições musicais, mas na ação, no que as pessoas fazem. É somente no ato de compreender o que as pessoas fazem, quando tomam parte num ato musical, que esperamos entender sua natureza e função que preenche na vida humana. (...) O livro, então, não é muito sobre música, mas sobre pessoas, como elas tocam e cantam, escutam e compõem e mesmo como elas dançam (porque em muitas culturas, música não acontece se ninguém está dançando, por ser tão integrado ao ato musical), e sobre a sua - nossa - maneira de cantar, tocar, compor e escutar(...). Eu propus esta definição: fazer música é participar com qualquer habilidade numa performance musical, providenciando material para a performance (chamado de composição), ou dançando. (SMALL, 1998, p. 8-9) (grifo meu)

\footnotetext{
3 Music, understood in an expanded African sense as akin to a Gesamtkunstwerk or total art work, is made by fetching and carrying songs, by beating drums, castanets and gourds, and by negotiating movement. Although individual acts that might suggest solo music-making exist, most musicmaking among the Northern Ewe is conceived in relation to other human actors. Like the pouring of libation, the performing of news, or the enactment of deceiving narratives, musicmaking is a thoroughly communal activity.
} 
Curiosamente no campo da educação musical se utilizam vários métodos de origem europeia, que muitas vezes se inspiram nas músicas não-europeias e suas qualidades musicais intrínsecas, sem que isso fosse notado pelos educadores musicais, que utilizam os métodos para iniciar musicalmente, no sentido da preparação para o 'SUM', sem contextualizar a contribuição de outras culturas e suas práticas integradas para a elaboração dessas propostas metodológicas: com a chegada de sonoridades e corporeidades de culturas não-europeias, foram concebidos no inicio do século $X X$, novas visões sobre a educação musical e rítmica, transformando ao longo de décadas, muitas atitudes e metodologias musicais, sendo que hoje na Europa as corporeidades, percussões e os repertórios das músicas do mundo estão inseridos em vários currículos escolares e universitários. Carl Orff, ha mais de um século, reconheceu a importância em criar uma escola interdisciplinar de música, ritmo e dança na Alemanha:

\begin{abstract}
O contexto histórico foi formado pela transformação cultural da virada do século (1890-1930), a orientação do modernismo para as artes não-europeias e a busca para um recomeço, em combinação com a redescoberta das origens, do primitivo e do elementar. No movimento rítmico e dançante trabalhavam Duncan, Dalcroze, von Laban, Wigman, não somente nas novas formas da dança e movimentação expressiva, mas nos fundamentos de uma percepção corporal e cinética. (...) Inspirações vieram da liderança na dança expressiva Mary Wigman (1886-1973) e do pesquisador musical Curt Sachs (1881-1959), conhecido pelas suas publicações na antropologia musical sobre danças e instrumentos musicais não-europeias. (...) A orquestra percussiva da Escola Mary Wigman em Dresden e os conhecimentos etnomusicologicos de C. Sachs sobre a importância universal da percussão na música e dança das culturas do mundo, levaram Carl Orff a um conceito de música, que vai além da música erudita europeia. Ele enfatiza o lado da percussão e do movimento rítmico do processo musical, o qual está muito próximo da perspectiva intercultural na contemporaneidade. ${ }^{4}$
\end{abstract}

Os métodos e pensamentos de Dalcroze, Orff entre outros, foram inspirados pelas mudanças socioculturais e politicas na Europa do inicio do sec. XX. Sobretudo nas artes foram incorporadas estéticas, criações e atitudes inovadoras, como fruto do colonialismo exploratório de culturas africanas, asiáticas e americanas que mais uma vez 'serviram' e até hoje 'servem' como manancial criativo para a devoração pelo Mundo Velho, sem receber reconhecimento e valorização dos criadores e contextos originais. Utilizar esses métodos somente a partir da sua visão eurocêntrica, seria negar a sua visão mais ampla, justo quando começa ser reconhecido a contribuição das músicas não-europeias. Nesse sentido, vale lembrar que a primeira grande escola musical de matriz africana, a partir do Blues e Jazz, começou a se espalhar pelo mundo, inclusive nas formações universitários ${ }^{5}$, sem que isso tivesse sido notado pela academia musical na América Latina durante décadas.

\footnotetext{
4 http://www.orff.de/orff-schulwerk/idee.html (acesso em janeiro 2017)

$5 \quad$ Na Alemanha, p. ex. tem cursos de graduação (com mestrado) em Jazz (e músicas populares) em 14 Universidades públicas, sendo que o primeiro curso em Jazz foi inaugurado no ano 1958 na Universidade de Köln, enquanto a Universidade Folkwang Essen, foi a primeira a oferecer um curso de graduação com mestrado para Performance em Jazz no ano 1988.
} 


\title{
II. Ritual experience, actionality, musicking - história social das músicas negras a partir da experiência e do Blues/Jazz e das músicas afro-latinas
}

Sem dúvida, a experiência do Blues e Jazz nos Estados Unidos, pode ser considerada uma das grandes criações da humanidade, portanto sim, tem um lugar de universalidade que gerou suas próprias formações, escolas, metodologias, epistemologias, críticas e filosofias no mundo inteiro, o que o historiador Hobsbawm chamou "um dos fenômenos culturais mais notáveis do nosso século." (1990, p. 27) Diferente de debates brasileiras sobre culturas negras e relações étnico-raciais que às vezes terminam num posicionamento 'ou um ou outro', no hemisfério norte vem surgindo a ideia da "dupla consciência" (Gilroy, 1993) que possibilita a visão das múltiplas identidades, um as well ... as..., (ambos também) possíveis:

\begin{abstract}
O percussionista Milford Graves sustenta que a música que ele toca, estaria "diretamente ligada à música africana". Mas ele também proclama: "Eu não lido com música que tenha qualquer classificação étnica. Eu lido com a música humana". Tais posições não são incomuns: os jazzistas afro-americanos frequentemente afirmam a propriedade negra de sua arte enquanto declaram que é universal ou a promovem como uma forma genericamente norte-americana. (...) E enquanto Duke Ellington disse que ele tocava "música negra", ele também insistiu que a arte é "internacional". (AUSTERLITZ, 2005, p. ix) ${ }^{6}$
\end{abstract}

Posicionamentos estéticos, culturais e filosóficos obviamente não são exclusivos e sim, podem somar, se complementar e contrastar também, porque isso seria essencialmente pensando cultura: a história social da cultura nesse sentido seria a compreensão de que os indivíduos e grupos se redefinem continuamente! A história sociocultural trata de sujeitos que vem de lugares, migram, e/ou são forçados a buscar novos contextos, muitas vezes dando continuidade ao que aprenderam, vivenciaram, e outras vezes rompendo com o que herdaram, e ainda como terceira via, criando sínteses, gerando novos caminhos, tradições culturais, nesse caso, musicais. A visão da grandiosidade dessa criação como p. ex. no Jazz, é compartilhada internacionalmente por muitos músicos e pesquisadores, vide O Livro do Jazz:

Nos anos de 1990, o jazz globalizou-se a uma velocidade incrivel. A grande síntese do jazz contemporâneo não acontece apenas na integração do velho com o novo, mas também em sua abertura crescente às outras tradições musicais. De fato, o interesse pela música africana, latino-americana e asiática perpassa toda a historia do jazz, mas os anos de 1990 foram especialmente ávidos em termos de multiculturalismo. (...) Jazz é música do mundo. E assim foi desde o começo - uma arte que surgiu em solo norte-americano pela interação de duas tradições musicais muito diferentes: a africana e a europeia. Jazz conta-nos histórias que

6 Percussionist Milford Graves maintains that the music he plays is "directly linked to African music." But he also proclaims, "I do not deal with music that has any ethnic classification. I deal with human music." Such positions are not uncommon: African American jazz players often assert black ownership of their art while declaring that it is universal or promoting it as a generically North American Form. (...) And while Duke Ellington said that he played "Negro music", he also insisted that art is "international". 
são como caminhos e mensagens aproximando as culturas do mundo. Não raro temos a sensação de que os músicos de jazz, em seus diálogos culturais, transcendem sociedades e épocas. (...) (HUESMANN, 2015, p. 26)

O que impressiona na vasta literatura sobre Jazz, é que os músicos, escritores e militantes negros, como também os pesquisadores da música negra americana, fazem sempre referência à tradição oral africano-americano, seu contexto e nascimento durante os séculos de escravatura, não como um passado obscuro, folclorizado ou supostamente primitivo, e sim, como um fundamento sociocultural, politico e estético, o qual nenhum músico negro jamais iria esquecer, tanto pela sua beleza estética, como pelo sofrimento coletivo vivido, nas palavras de dois ícones da história e cultura negra norte-americana, Du Bois e Leroi Jones:

\begin{abstract}
Pouca beleza América tem dado ao mundo, salvo a grosseira grandeza que o próprio Deus estampou em seu peito; o espírito humano neste novo mundo se expressou em vigor e ingenuidade, e não em beleza. E assim, por acaso fatal, a canção popular negra - o grito rítmico do escravo - permanece hoje não apenas como o solo da música americana, mas como a mais bela expressão da experiência humana, nascida deste lado do atlântico. Foi negligenciada, tem sido e é meio desprezada e, acima de tudo, tem sido persistentemente mal-entendida de forma equivocada; mas, apesar disso, ainda permanece como a herança espiritual singular da nação e o maior presente do povo negro. (DU BOIS,1989, p. 205) ${ }^{7}$

Negros tocavam jazz como cantaram blues ou, ainda mais cedo, como gritaram naqueles campos anônimos, porque era uma das poucas áreas de expressão humana à sua disposição. Os negros que sentiam o impulso do blues, depois jazz, como um meio específico de expressão, iam naturalmente para o cerne dessa música. (...) O jazz, como música negra, existia até a época das grandes bandas, no mesmo nível sociocultural da subcultura da qual foi originado. A música e sua inspiração eram segredos, no que dizia respeito ao resto da América, no mesmo sentido em que a vida real do negro era desconhecida para o americano branco. (JONES, 2010, p. 16-17) ${ }^{8}$
\end{abstract}

A música de tradição oral, não visão dos estudiosos do Jazz, por mais que seja também uma memória do passado e referência ancestral, também pode ser uma porta para uma visão musical diferente da música ocidental, não como algo passado, diminutivo, arcaico e sim, como a chance no Novo Mundo de compreender e perceber a criação e percepção musical numa integridade e holística sócio-musical, que na música central-europeia se perdeu em parte. O encontro com músicas africanas poderia servir 
também para compreender melhor o fazer musical desde das bases europeias, o que muitos etnomusicologos vivenciaram, ao exemplo de Herbert Pepper que viveu durante onze anos na floresta do Congo e Gabão:

Tive a impressão de que aprendi mais sobre a minha arte na escola africana do que na escola ocidental. Esta última certamente me ensinou a apreciar a qualidade do artigo acabado, mas às vezes parecia tão distante do mundo cotidiano que comecei a me perguntar se ele tinha alguma relação com este. A escola africana, por outro lado, me ensinou que o que importa, não é a qualidade da música em si, mas sua capacidade de processar emoções e desejos da forma mais natural possível. (PEPPER, em BEBEY, 1975, p. 5) ${ }^{9}$

Embora a transformação das músicas negras - desde do spiritual, gospel e blues para vários gêneros instrumentais ou não, englobados no termo Jazz, com sua própria estética, metodologia e teoria musical - pode ter em parte semelhanças com a história da música europeia, os músicos negros no processo histórico do blues e do jazz nunca perderam a referência da sua oralidade e a consciência sobre o processo de desenvolvimento de música negra que se deu por causa dos esforços coletivos dos negros que queriam libertar e revelar as origens e raízes da suas práticas musicais, o que os une pela sua experiência ritual coletiva:

Ele (Charlie Parker) representou a reintrodução de um principio que Sowande chamou ritual experience, e compreendeu sua música como expressão de pessoas que vivem numa diáspora cultural. (...) com outras palavras: o motivo para a concepção dessa nova linguagem estava na necessidade para uma estética nova além da teoria acadêmica ocidental ... (SHEPP em SIDRAN, 1985, p. 15)

Mediante essa experiência-resistência, ritual experience, os negros norte-americanos preservaram sua cultura e consciência da oralidade e expandir além das fronteiras, com isso gerando nas Américas, uma sub - e contracultura, com estruturas sociais e est/éticas próprias. Elas influenciaram sua própria percepção e construção criativa, que por sua vez voltou para as estruturas, o que pode ser demonstrado ao exemplo dos múltiplos gêneros musicais negros nesse tronco ancestral, chamado Jazz. A cultura oral estava nas sombras, se desenvolveu no escondido, portanto primeiro não gerou resistência, foi praticamente ignorado, ou, como seria mais o caso do Brasil, ridicularizado e marginalizado pela hegemônica branca e epistemologia eurocêntrica: uma atitude que parece ter abrandado, mas que de certa forma continua com uma atitude de condescendência de muitos músicos brancos (contextos musicais brancos) sobre músicos negros (contextos musicais negros.)

Nas artes e comunidades musicais da diáspora africana, a consciência da sua oralidade não exclui a literalidade: a genialidade estaria justamente na combinação e junção das duas, as quais, no entanto, são mal compreendidas. Na cultura da oralidade, todas 
as informações necessitam de serem memorizadas a partir das palavras emitidas, em conjunto com sons, gestos, vocalizações e suas variações, dessa maneira formando os objetos imateriais de referência para a percepção na tradição oral. Estes sons vocais, por sua vez, estão intrinsecamente ligados ao fenômeno do tempo e são ouvidos, como pronunciados, tanto pelo conteúdo em si, como pela emissão sonora, rítmica, mímica, gestual e encorpada, formando um fluxo sonoro e expressivo no tempo, que nunca acontecerá da mesma maneira. As formas de comunicação nas tradições orais se baseiam na presença, prontidão, participação e iminência, num coletivo que compartilha os mesmos códigos sonoramente encorpados e que sabe que 'o meio é a mensagem', ou, na visão asiática: o caminho é o objetivo! Portanto, podemos compreender porque nas artes musicais africanas se destacam dois fatores que estão onipresentes: 0 tom vocal e a rítmica especifica e complexa, elementos que formam a essência da comunicação oral e possibilitam a comunicação não-verbal que muitas vezes está num plano inconsciente, velado ou implícito.

Estes elementos musicais se sobressaem e parecem estar mais fortes que nunca, apesar de tanta repressão, perseguição e proibição. O som vocal, aliado as expressões mímicas e gestuais, funciona como base elementar oferecendo vários fenômenos sonoros que emprestam à língua uma qualidade semântica, que não poderia nunca ser transmitida e traduzida na linguagem impressa, tampouco na fixação do pentagrama tradicional da música europeia. As línguas tonais africanas fazem oposição ao ideal ocidental - que preza pela moderação de altura, tempo, dinamização e tom da fala - por valorizar e empregar vocalizações extremas e expressivas, recheados de rodeios, ornamentos, imprecisões sonoras e temporais do que uma formulação e entonação precisa e perfeita. O ideal sonoro e estética não seria de chegar na perfeição, muito mais de experimentar com as inúmeras possibilidades e variações antes de chegar a uma sonoridade, que seria algo próximo a uma suposta perfeição. Nenhum tom se pronuncia com a mesma exatidão, porque a voz ou o instrumento o aborda intuitivamente de cima ou de baixo, aproximando-se, 'brincando', criando uma relação com o som, enquanto o timbre, a coloração que queira se dar a esse tom, a essa 'nota', passa por mutações permanentes, de acordo com o uso de vibrato, trêmulo e sons harmônicos.

A música e cultura ocidental expõe uma característica forte em dominar o fator tempo, querendo fixar o tempo em partituras, em padrões e ritmos rígidos, fazendo com que a música virasse um objeto materializado, uma equação matemática, sem fluir no tempo (na visão africana: o tempo dos homens, dos espíritos, da natureza, o tempo do tempo, sempre fluido e relativo ao contexto, tanto aos impulsos externos, como aos impulsos subjetivos). A música ocidental deslocou a percepção e expressão musical do temporal para o espacial, de aural para o visual, com isso fixando e congelando os fenômenos sonoros em objetos, transformando-os em signos espaciais e materiais (impresso, pintado, desenhado, gravura), enquanto na verdade a língua e a música (o movimento, a dança etc.) seriam signos temporais.

O membro da oral culture, desenvolve uma relação muito particular com o fator tempo: ele se vê obrigado a um comportamento espontâneo, precisa agir e reagir ao mesmo tempo. Nunca estará em distanciamento intelectual perante seu 
ambiente, mas se encontra emocionalmente acolhido, o que pode ser compreendido com o conceito do Actionality, ou seja, a orientação pelo ato, pelo fazer (...). Sendo que os sons são fugazes, é necessário de criar respostas e interações imediatas para se inserir e participar. (SIDRAN, 1985, p. 29)

Sidran gera o conceito do Actionality (estar em ação) para compreender um princípio fundador do fazer musical negro que combina com o conceito do Social Music que se compreende pela interação social: o fazer musical enquanto ser social que se comunica e atua mediante a expressão musical. A compreensão do etos das músicas negras que encontram sua origem na filosofia e vida comunitária africana e reforçaram os laços sociais ao longo da crueldade escravocrata - onde todas as pessoas negras precisavam da comunidade, de união, de confiança e de meios de comunicação secretos - se expressa mediante os conceitos do musicking, ritual experience, actionality e social music.

As estéticas musicais europeias e africanas, são duas estratégias quase opostas, porém podem ser dois caminhos complementares que de forma alguma se excluem, porque oferecem muitas qualidades intrínsecas, aplicadas ao fazer, aprender e apreciar musical! Ambas as formas representam soluções, criações e bases teóricas complementares que na realidade levariam a uma criação musical mais competente, literalmente em todos os sentidos. Eis que Gilroy identificou como "dupla consciência" e bi-musicalidade, na qual se inserem músicos africanos e afro-latinos por serem capazes de expressar-se musicalmente pelo padrão europeu: centrado na partitura e regência, afinação temperada de orquestra, separado de uma audiência em disciplinado silêncio, hierárquico e divisório; ao mesmo passo que mudam o comportamento musical quando surge uma prática musical afro-latina, e todos começam a se entrosar, se olhando, improvisando e chamando as pessoas ao redor para interagir dançando, cantando, batendo palmas no sentido do centramento circular, interativo, igualitário, inclusivo. Importante lembrar de que esse debate quer retomar a importância e a sabedoria integrada das culturas e músicas de tradição oral, e não as reduzir e opô-las à literalidade e com isso estigmatizar mais uma vez a imagem dos povos negros supostamente 'iliteratos', focados no corporal e emocional, sem atividade intelectual - um preconceito racial que teria gerado uma visão "bipolar" no Brasil, segundo Malo-Malo:

Os descendentes que foram privados do acesso à "língua escrita", vista como a cultura erudita, reinventaram, na diáspora, a "cultura popular negra", que tem a oralidade como o elemento principal (HALL, 2003). Davi Treece (2003, p. 53) chama a atenção para que não se reduza toda a produção musical da diáspora negra a esse aspecto, correndo o risco de reforçar o paradigma dominante que identifica a musicalidade negra, exclusivamente, com o corpo, o gesto, o ritmo, o tambor; compensando e contrapondo-se, assim, a uma suposta deficiência intelectual e linguística atribuída, implícita, ou explicitamente, ao "afrodescendente". Contra esse paradigma, pelo menos no contexto da música popular brasileira (MPB), ele identifica a existência de uma "poética da palavra cantada" produzida pelos negros da diáspora brasileira, contrariando o paradigma bipolar da MPB, segundo o qual de um lado está a dimensão letrada, melódico-harmônica, cerebral, que é de origem europeia; e de outro lado está a dimensão corporal, percussiva e rítmica, de raiz africana. $O$ autor defende a tese de que essas duas 
dimensões se encontram, conjuntamente, fundidas no seio das tradições estéticas afro-brasileiras ou negras. Ou seja, há uma mestiçagem da escrita e da oralidade. (MALOMALO, 2017, p. 186-187)

A diáspora africana como complexo político, histórico, sociocultural e artístico tem sido pesquisado, registrado, cantado, dançado e debatido nas últimas décadas nas Américas e na Europa, porém com pouca intensidade nos países da América Latina, muito embora as artes musicais da diáspora africana criaram fortes laços entre descendentes africanos, e por parte entre povos indígenas e imigrantes europeus em toda parte do Mundo Novo:

O Caribe e suas adjacências oferecem um espaço especialmente interessante para pensar sobre as relações e influências musicais da diáspora negra. É uma região que se tornou o lar de mais de quatro milhões de africanos deslocados durante a vigência do comércio de escravos no Atlântico e coletivamente é um número maior até do que no Brasil. Atualmente seus moradores são principalmente descendentes de africanos ou mestiços e fazem inúmeras formas de música, muitas delas demonstrando características proeminentes de derivações africanas e/ou de ligações com outras formas musicais afro-diaspóricas da região e arredores. Desta forma, existem numerosos exemplos de tradições que ligam o Caribe a África musical, linguística ou ideologicamente, que definem os setores da população afro-caribenha como distintos de outros, e que criam afinidades com uma noção mais ampla de patrimônio diaspórico compartilhado. (MOORE, 2012, p. 306)

Inúmeras formas e criações cênico-poético-musicais se consagraram nas culturas afro-latinas, crioulas, mestiças, que surgiram entre os descendentes africanos no Mundo Novo: a emergência de centenas de gêneros e estilos musicais e dançantes que mais tarde seriam eternizados na história do Blues e Jazz, dos ritmos afro-cubanos, sambas brasileiros entre muitos outros e que foram geradas durante os séculos XVIII e XIX culminado nas suas formas determinantes ao longo do século XX. Além das características regionais, que se cristalizaram durante décadas, a partir de meados do século XX, com a expansão global do consumo musical e das novas tecnologias, surgem diálogos criativos na diáspora africana.

Os Insights fornecidos por Juan Flores e outros nos Estudos Latinos demonstram que "América" é uma fronteira contestada e problemática: estamos continuamente redefinindo o que significa ser nativo, anglo, latino, branco ou negro americano. Como diz o compositor de salsa Ruben Blades, estamos sempre "buscando América", sempre procurando, descobrindo e inventando América. (AUSTERLITZ, 2005, p. 6) ${ }^{10}$

A busca pelas Américas que reconhece traços em comum, fortemente marcados pelas musicalidades e danças negras e crioulas, encontra-se pouco presente nas pes-

\footnotetext{
10 Insights provided by Juan Flores and other in Latino Studies demonstrate that "America" is a contested and troubled borderland: we are continually redefining what it means to be Native, Anglo, Latin, white or black American. As salsa composer Ruben Blades puts it, we are perpetually "buscando América", we are always searching for, discovering, and inventing America.
} 
quisas, grupos de estudos, e bibliotecas brasileiras, enquanto nos Estados Unidos, existe um Centro de Pesquisa da Música Negra (Center of Black Music Research), desde o ano $1983^{11}$. Na cultura acadêmica do campo da música, existe pouco material de estudo e debate sobre músicas e culturas afro-americanas, afro-caribenhas e afro-latinas, apesar de vários territórios em comum, no seu processo criativo, histórico e civilizatório:

Os processos de poiesis musical na expressão das artes expressivas negras deram lugar a transformação e criação de novas formas introduzindo ou acentuando diferenças entre as Américas e o Caribe e a(s) África(s). Grandes orquestras de percussão, como os blocos carnavalescos de samba no Brasil, os blocos carnavalescos afro-uruguaios e afro-cubanos (comparsas) e os iron-bands de Trindade-Tobago são criações contemporâneas, sul-americanas e caribenhas, bem como as big-band do jazz ou da salsa nos EUA e no Caribe. (MAKL, 2011, p. 61)

Portanto, torna-se necessário, de aprofundar as pesquisas e leituras sobre a história, desdobramentos e criações das artes musicais africanas e da diáspora africana e gerar publicações que contribuem para a formação de pesquisadores/professores na América Latina, que em boa parte desconhece a história dos grandes gêneros musicais negros e afro-latinos nas Américas do Norte ao Sul. Além disso, é quase inexistente o acesso e o debate da literatura consagrada: Black Talk, (SIDRAN, 1985); Music of the Common Tongue, (SMALL, 1987/1998); Music and Black Ethnicity, (BEHAGUE, 1992); The Power of Black Music: Interpreting Its History from Africa to the United States, (FLOYD Jr., 1995) Caribbean currents, (MANUEL, 1995); Blackness in Latin America and the Caribbean, (WHITTEN, TORRES, 1998, vol I \& II); Black Music of two worlds, (STORM, 1998); Africa and the Blues, (KUBICK, 1999); Jazz Consciousness, (AUSTERLITZ, 2005); entre muitos outros, assim como recentemente a obra-prima The Transformation of Black Music: The Rhythms, the Songs, and the Ships of the African Diaspora, (FLOYD Jr., ZECK, RAMSEY, 2017).

A carência de debates e estudos, está mais alarmante nos cursos universitários de música, sobretudo na formação de educação musical. Nem mesmo o samba e suas vertentes, consta como objeto de estudos nos cursos de música, e quando tematizado na vasta literatura existente, pouco é dada ênfase ao samba enquanto música afro- brasileira, ressaltando suas qualidades específicas enquanto expressão musical e performática da diáspora africana, geralmente com foco maior na 'brasilidade', segundo Gérard Béhague:

Ninguém pode negar o papel significativo desempenhado pelos afro-brasileiros na invenção e desenvolvimento do samba. E ninguém pode negar a existência de uma forte repressão da cultura popular afro-brasileira, uma repressão que influenciou bastante marcadamente a história do samba. Mas, ao mesmo tempo, é preciso reconhecer que, em justaposição a essa repressão, outros laços uniam membros da elite brasileira e classes sociais populares, facilitando a definição da nacionalidade brasileira centrada no conceito de miscigenação ou no orgulho

11 https://www.colum.edu/cbmr/about_the_center.html 
dos elementos mestiços da cultura popular. Assim, o samba urbano continua sendo parte integrante do processo de construção nacional e da invenção do "brasilianismo". ${ }^{12}$ (2006, p. 83-84)

O debate sobre artes musicais africanas e da diáspora africana historicamente foi mais presente na etnomusicologia ou musicologia cultural e histórica nas obras de Nei Lopes, Muniz Sodré, José Jorge Carvalho, Rita Segato, Tiago de Oliveira Pinto, Angela Lühning, Elisabeth Travassos, Glaura Lucas, Alberto Ikeda, Samuel Araújo, Espirito Santo. Durante duas décadas vem crescendo atuação de pesquisadores entre antropologia, história social/oral e etnomusicologia que tem contribuído com trabalhos acadêmicos e projetos culturais interdisciplinares: Paulo Dias, Denise Barata, Luís F. Makl, Salloma Salomão, Magda Pucci, Luciana Prass, Katharina Döring, Rafael Galante, Flavia Candusso e Ari Lima que tem exposto o discurso embranquecido, que muitas vezes nega a negritude ao samba:

De fato, baianos e cariocas, sambistas e estudiosos do samba no Brasil incorrem numa inadequação, uma vez que em seus discursos de origem e disputa pelo samba nacional e mestiço ratificam um programa institucionalizado pelas elites, que exclui as camadas populares e negras ou as assimila para civilizá-las e modernizá-las. Defendo, então, que o samba é carioca ou baiano apenas como discurso de segunda ordem, e, ao contrário disso, é negro-africano. Ou seja, é resultado da agência de produtores de culturas negro-africanas correlatas, afirmativas, específicas em suas rupturas e descontinuidades na Bahia ou no Rio de Janeiro. Esteve submetido à racialização, à a-historicidade, à estetização e ao apagamento da agência de africanos e descendentes que, no Brasil, ora se dirigiram a África como mito, ideologia, supraterritório ou transitividade, ora em direção à sua representação brasileira como "negro" subalterno. (LIMA, 2013, p. 132)

A produção de pesquisas e literaturas especificas nos campos da antropologia, história social da cultura e etnomusicologia, partiram algumas vezes de pesquisadores estrangeiros, residentes no Brasil, p. ex. grupo de pesquisa S.A.M.B.A. na Bahia ${ }^{13}$; a atuação de Gerhard Kubik, Gérard Béhague, Kazadi Wa Mukuna, Kabenguele Munanga, Christopher Dunn e recentemente Bas 'Ilele Malo-Malo.

A maioria das pesquisas sobre questões africanas foi feita por estudiosos fora da África. A África realizou muito pouca pesquisa sobre sua própria música. Eu não os estou criticando [os não-africanos], mas é notável que muitos dos pesquisadores da música africana carregam nomes ocidentais. Onde estão os nomes africanos fazendo pesquisas sobre sua própria música africana? (HERBST, 2005, p. 17) ${ }^{14}$

\footnotetext{
12 No one can deny the significant role played by Afro-Brazilians in the invention and development of the samba. And no one can deny the existence of a strong repression of Afro-Brazilian popular culture, a repression that influenced quite markedly the history of the samba. But concurrently one must recognize that, in juxtaposition with this repression, other ties united members of the Brazilian elite and popular social classes, facilitating a definition of Brazilian nationality centered on the concept of miscegenation or pride in the mestizo elements of popular culture. Thus, urban samba continues to be an integral part of the process of national construction and of the invention of "Brazilianism."

130 grupo S.A.M.B.A. (Coord.: Livio Sansone e Angela Lühning) fez parte do programa A Cor da Bahia nos anos 90 e resultou na publicação do livro "Ritmos em Transito-Socioantropologia da música na Bahia" (1997)

14 The majority of research on African issues has been done by scholars outside of Africa. Africa has conducted very little research on its own music. I am not criticising them [the non-African], but it is conspicuous that many of the researchers on African music carry Western names. Where are the African names doing research on their own African music?
} 
O interesse pelas músicas do tronco musical africano no Brasil e na América Latina por muitos pesquisadores de origem europeia, encontra um fenômeno semelhante nas pesquisas musicais em países africanos, que gerou resultados importantes, porém, apela pela participação engajada em pesquisas e projetos, dos estudiosos para sua cultura local e regional, levantando questionamentos e apontando para as lacunas e demandas de pesquisa.

\section{Pensando uma educação musical para as performances cênico- poético-musicais na diáspora africana}

Há mais de quarenta anos atrás H. J. Koellreutter reformulava o modelo para a formação musical universitária que precisava se distanciar do atitude conservatorial europeia do século XIX, e criar formações práticas para o Brasil no que ele chamou de "mundo modificado" (1977), depois de reconhecer que o legado musical europeu só servia para uma elite privilegiada, e que a educação musical "era usada com um método de seleção e de controle com o propósito de manter este estado de coisas - de alienação social e de isolamento do artista e de desconhecimento da arte." (1977). Décadas depois, mesmo face à mudanças socioculturais e afirmações identitarias, percebe-se que a formação musical no Brasil, continua sendo prioritariamente branca, elitista, excludente, separado do fazer musical da sociedade e das suas culturas musicais mais diversas. Portanto, vale a pena de reler alguns dos pensamentos de Koellreutter, que deixou uma memória considerável nas escolas musicais:

O curso básico introdutório de dois semestres consistiria de uma introdução à semiologia da música, isto é, uma extensão da teoria da música em relação à música asiática e africana e à notação da música moderna, treinamento auditivo, história comparada da música, estilística e terminología, bem como um curso prático de um instrumento ou de canto. Por treinamento auditivo eu entendo aqui uma extensão do curso normal de solfejo, inclusive o estudo auditivo das linguagens musicais do século XX e da música asiática e africana, tais como o conceito qualitativo de tempo, ritmo, intuitivo, microtons, variação rítmica e melódica, heterofonia, modelos de forma variável, etc. O curso de terminología consistiria na explicação e definição de termos técnicos da música ocidental bem como da música asiática e africana assim como do estudo comparativo dos mesmos. Cada um dos seis cursos especializados consistiria de uma matéria principal e de uma seleção adequada das seguintes matérias suplementares de produção e reprodução musical e de musicologia, ou sejam: teoria do texto musical, analítica e sintética - isto é, uma aplicação da teoria de informação à música, que permite a análise de todos os estilos e gêneros de música, portanto também da música asiática e africana, sob o mesmo ponto de vista, estudos analíticos e comparativos da história dos sistemas de estruturação musical, eletroacústica e estatística, morfologia, estética comparada, psicologia e sociologia da música. Além disso haveria oficinas práticas e teóricas para improvisação, individual e coletiva. Atenção especial seria dada, nesse programa, à música recreativa, popular e ao jazz, assim como à música asiática e africana, que até agora só excepcionalmente têm sido incluídas nos currículos das escolas ocidentais de música. (KOELLREUTTER, 1977) (grifo meu) 
Koellreutter se interessava por filosofia, metafisica, espiritualidade e pesquisava como as sonoridades e músicas se relacionavam com os processos da vida, demonstrando abertura e consciência para a diversidade musical no mundo e outros temas correlatos. $O$ educador musical e professor Carlos Kater me contou ${ }^{15}$ que no final da vida dele, dando aula em São Paulo, ao se deparar com algumas músicas de congadas, reisados, sambas, jongos entre outros, trazidos pelos novos estudantes da época, Koellreutter teria se emocionado a dizer: "porque vocês nunca me mostraram essas músicas antes?" - reconhecendo o imenso potencial criativo e sonoro dos elementos ancestrais dessas musicalidades.

Desde do meu mestrado em etnomusicologia (2002), procurei a inserção da riqueza e diversidade sonora, poética e cênica das musicalidades da tradições orais e culturas populares e negras brasileiras, em contextos performáticos e educacionais contemporâneos, estruturando algumas características para uma Escola de Música e Artes com identidade brasileira, propondo os seguintes eixos transversais: Interdisciplinaridade (entre varias áreas: etnomusicologia, sócio-antropologia, história, produção cultural, comunicação, literatura, arte-educação, ludicidade, artes cênicas); Diversidade musical (diversidade de gêneros cênico-musicais e suas variações locais em termos de ritmos, melodias, harmonias, arranjos, tonalidades, timbres vocais e instrumentais, poesias, instrumentos, materiais, técnicas entre outros); Integração artística e cultural (expressões musicais culturais com outras linguagens artísticas, dança, teatro, literatura oral, estética e artes visuais); Perspectiva profissional contemporânea (formando músicos em diversos estilos de execução, educadores musicais, diretores musicais, arranjadores, compositores, técnicos de gravação e mixagem, produtores musicais, críticos, pesquisadores e radialistas e artistas interdisciplinares); Relação com a comunidade (trocar privilégios com as pessoas e regiões que produzem e preservam as riquezas culturais; inclusão de mestres e músicos da cultura popular ao corpo docente; elaboração de projetos paralelos nas comunidades) (DORING, 2006, p. 180-181)

Nos últimos anos, tem sido debatido no Brasil e por toda parte do mundo na educação musical, a necessidade de uma concepção pedagógica musical orgânica e comunitária e a inserção dos mestres e mestras das tradições orais e culturas populares. Por outro lado, essas indagações sempre estiveram presente no contexto cultural de músicas africanas, segundo Nketia que descreveu a educação musical comunitária na África desde os anos 70: "Música africana deve ser vista em vários níveis de abstração; a) o nível conceitual ou nível de teoria; b) o nível processual ou nível de criatividade e performance; c) o nível de valores, inclusive valores estéticos e sociais; d) o nível do contexto" (1999, p. 55). As artes musicais africanas (e da diáspora africana) colocam sua ênfase em valores complexos e entrelaçados que prezam pela escuta, observação e participação sociais ativas, enquanto relação e experiência sociais, compartilhadas pela comunidade, sem linha divisória entre audiência e performance. 
Os vários níveis contextuais, imprescindíveis para a compreensão, interpretação e a transmissão das artes musicais africanas, foram mencionados por Leroi Jones acerca do jazz, como paradigma para a construção curricular e epistemológica: não se pode pensar em ensinar e transmitir essas musicalidades sem os contextos socioculturais, apenas pensando nas ferramentas metodológicas convencionadas na música ocidental, porque perderia o sentido:

Um exemplo musical impresso de um solo de Armstrong, ou de um solo de Thelonious Monk, não nos diz quase nada, exceto a futilidade da musicologia formal ao lidar com o jazz. Não são apenas os vários efeitos do jazz quase impossíveis de serem notados, mas cada nota significa algo a mais em complemento à notação musical (...) Os gritos de Coltrane não são "musicais", mas são música e bastante comovente. Os gritos e reclamações de Ornette Coleman são somente musicais, uma vez que se entende a música, que sua atitude emocional procura criar. Essa atitude é real e talvez o aspecto mais importante de sua música. (JONES, 2010, p. 18-19) ${ }^{16}$

Na crítica de jazz, nenhuma confiança na tradição ou teoria europeia ajudará em nada. A música negra, como o próprio negro, é estritamente um fenómeno americano, e temos que estabelecer padrões de julgamento e excelência estética que dependem do nosso conhecimento nativo e da compreensão das filosofias subjacentes e das referências culturais locais que produziram o blues e o jazz para produzir escrita crítica válida ou comentário sobre isso. (JONES, 2010, p. 24$)^{17}$

O músico, professor e pesquisador Huib Schippers ${ }^{18}$, por sua vez, elaborou um arcabouço teórico multifacetado com vários eixos estruturantes a partir de tradições musicais comunitárias que procura agregar e comparar conceitos e bases de músicas ocidentais, com valores e estruturas musicais indígenas, asiáticas e africanas entre outros. Ele não foca somente nas artes musicais africanas, mas fornece categorias estruturantes para a compreensão e o ensino de músicas populares, comunitárias e de tradição oral que podem ser adaptadas a cada contexto local. Schippers se refere aos vários planos subjacentes nas músicas africanas e procura estruturas semelhantes para as músicas do mundo, ou seja, as comunidades musicais, onde as práticas são predominantemente aurais, com espaço para improvisação, mudanças orgânicas nas performances, sicology when dealing with jazz. Not only are the various jazz effects almost impossible to notate, but each note means something quite in adjunct to musical notation... Coltrane's cries are not "musical", but they are music and quite moving music. Ornette Coleman's screams and rants are only musical once one understands the music, his emotional attitude seeks to create. This attitude is real, and perhaps the most singularly important aspect of his music.

17 In jazz criticism, no reliance on European tradition or theory will help at all. Negro music, like the Negro himself, is strictly an American Phenomenon, and we have got to set up standards of judgment and aesthetic excellence that depend on our native knowledge and understanding of the underlying philosophies and local cultural references that produced blues and jazz in order to produce valid critical writing or commentary about it.

18 Schippers, desde de 2016, diretor e curador da Smithsonian Folkways Recordings. De 2003-2015, foi o diretor do Queensland Conservatorium Research Centre, universidade de Griffith (Australia), onde coordenou inúmeros projetos inovadores nas interfaces: pesquisa, educação, performance, comunidade; como nas Universidades do Rotterdam e Amsterdam, desenvolvendo os currículos para World Music and Dance Center; Intercultural curriculum and Diversity in Art Educaction; Sustainable Futures for Music Education. O livro "Facing the music: Shaping music education from a global perspective", traduzido em cinco idiomas, serve como obra de referência para trabalhos na linha de diversidade cultural e músicas do mundo na educação musical. 
estruturas cíclicas com ritmos livros, uma linha melódica central e flexibilidade para a entonação diferente entre várias obras e performances. Na comparação com a musica clássica ocidental, ele destaca as características das composições fixas e centralizadas, em peças musicais relativamente estáticas, com relação complexa entre varias linhas melódicas, base num metro linear e regular, e um sistema de entonação único para todas as obras. Ele oferece várias tabelas comparativas que servem como orientação para aplicar um ensino musical mais consciente entre dois ou mais sistemas:

\begin{tabular}{|c|c|}
\hline \multicolumn{2}{|c|}{ Indicadores para modos de transmissão } \\
\hline Atomístico / analítico & Holístico \\
\hline $\begin{array}{l}\text { Uso de musicas didáticas como exercícios } \\
\text { gradativos e estudos }\end{array}$ & $\begin{array}{l}\text { Repertorio "real" servindo como base para a atual } \\
\text { transmissão }\end{array}$ \\
\hline Teoria musical explicita & Teoria musical implícita \\
\hline $\begin{array}{l}\text { Quantidade substancial de falar e explicar durante } \\
\text { transmissão musical }\end{array}$ & $\begin{array}{l}\text { Relativamente pouca fala e explicação durante } \\
\text { transmissão musical }\end{array}$ \\
\hline Progresso consciente do simples ao complexo & Progresso intuitivo: conhecido ao não-conhecido \\
\hline $\begin{array}{l}\text { Baseado em currículo, muitas vezes com } \\
\text { estruturais formais e provas }\end{array}$ & $\begin{array}{l}\text { Caminho individual, "confusão" usado como } \\
\text { instrumento (in-) consciente }\end{array}$ \\
\hline $\begin{array}{l}\text { O professor guia e controla o processo de } \\
\text { aprendizagem numa relação didática }\end{array}$ & $\begin{array}{l}\text { O professor demonstra, supervisiona ou pode ate } \\
\text { ser ausente (a distancia) }\end{array}$ \\
\hline Literalidade & Auralidade \\
\hline $\begin{array}{l}\text { Existe um corpo central de repertórios com } \\
\text { notação prescritiva usado pelos performers }\end{array}$ & Nenhuma ou pouca notação é utilizada \\
\hline $\begin{array}{l}\text { Estudantes podem receber material para estudar } \\
\text { com notação sem ouvir antes }\end{array}$ & $\begin{array}{l}\text { O material tonal amplamente improvisado (ou } \\
\text { reestruturado) }\end{array}$ \\
\hline Tangível & Intangível \\
\hline Ênfase na técnica instrumental & Ênfase na expressão \\
\hline Ênfase no repertorio bem definido & Ênfase na criatividade e improvisação \\
\hline Ênfase na teoria & $\begin{array}{l}\text { Ênfase no abstrato, espiritual, e valores } \\
\text { metafísicos }\end{array}$ \\
\hline
\end{tabular}

(SCHIPPERS, 2010, p. 120)

Aqui não é possível apresentar todas as propostas estruturantes e modelos curriculares na obra de Schippers, porém, certamente é possível e necessário de adaptar e aplicar vários dos conceitos e eixos norteadores para a elaboração de um sistema de ensino musical das artes musicais da diáspora africana no Brasil e na América Latina, p. ex. utilizando os quatro pilares sugeridos por Schippers: questões de contexto; modos de transmissão; dimensões de interação; abordagem da diversidade cultural.

A área de etnomusicologia na América Latina tem trilhado nesse sentido muito mais intensamente do que a área de educação musical que tradicionalmente insiste focando quase que exclusivamente no objeto musical a partir do 'SUM', sem levar em conta o mundo musical e cultural das pessoas, embora esteja mudando bastante nos 
últimos anos com maiores diálogos entre as duas áreas e a sociologia das comunidades, segundo Lühning:

\begin{abstract}
Partindo de um texto de Turino (2009, p.111-114) faço uma livre paráfrase: a presença de práticas musicais participativas em contextos sociais comunitárias vivos permite continuação, mas nem a etnomusicologia e nem a educação musical podem preservar ou sustentar tradições musicais, embora possam aprender com e falar sobre elas. É preciso permitir que se perceba a importância de experiências como aquelas, presentes nas comunidades, mas sem querer imitá-las, transplantando as músicas em conjuntos participativos. Pois, não tem como transplantar uma experiência coletiva de qualquer música sem o respectivo contexto social participativo. (LÜHNING, 2013, p. 55)
\end{abstract}

Uma das maiores referências da educação musical na África Contemporânea é o professor e pesquisador sul-africano Meki Nzewi que ha muitos anos pesquisa e ensina um caminho metodológico para as artes musicais africanas, investigando suas dinâmicas intrínsecas, filosoficamente embasado pelos autores contemporâneos e a própria cosmovisão dos demais povos africanos que só pode ser compreendido a partir da visão êmica das respectivas culturas. Ele gera uma epistemologia dos saberes da tradição oral, e a relaciona e aplica a educação de artes musicais africanas, que serve tanto para a educação escolar contemporânea como para projetos comunitários. Nzewi publicou a série A contemporary study of musical arts informed by African indigenous knowledge systems em cinco volumes (2007), como módulos de educação musical aplicada, utilizando também estruturas musicais e conceituais europeias, para compara-las e transforma-las em formas musicais que se relacionam com as artes musicais africanas, referente à notação e teoria musical, compreensão de estruturas musicais, composição, organologia, performance e teatro musical, pesquisa na sociologia e etnomusicologia, percepção e apreciação musical, educação musical e cênica, e muitos eixos transversais que tratam das experiências ocidentais de forma igualitária e comparativa com as experiências históricas e contemporâneas nas artes musicais africanas.

Uma posição que é evidente em todo o trabalho de Nzewi é uma profunda desconfiança de visões não centradas na África. (Por favor, note que 'não centrada na África' não é o mesmo que 'não-africana'.) Esta é uma posição complexa que sofreu redefinição no curso de muitos escritos, e sem dúvida continuará a ser modificada com a acumulação de novos contextos e experiências nos próximos anos. A rejeição de Nzewi às visões não centradas na África não é redutível a uma dicotomia banal entre nós e contra elas; nem é uma daquelas posições de deixar-nos-estudar-nos. Não é um tipo de visão de portador de cultura, que não pode ser errado; não é um abraço grosseiro da negritude e uma resistência de princípios à brancura. De fato, Nzewi é igualmente crítico dos escritores africanos e não africanos. Ele critica os escritores africanos que aceitam inquestionavelmente uma estrutura epistemológica ocidental, bem como os não-africanos que se recusam a ser instruídos pelas perspectivas africanas indígenas e que insistem em impor categorias ocidentais na música africana. Suas posições 
derivam de uma crença - dificilmente controversa - de que um pré-requisito para escrever sobre uma cultura musical é que o pesquisador conheça essa cultura de dentro, das perspectivas disponibilizadas pelos portadores de cultura. (AGAWU, 2008, p. 5) ${ }^{19}$

O trabalho pioneiro de Meki Nzewi mereceria um dossiê inteiro a ser publicado na América Latina, e a série acima mencionada poderia servir de modelo para pensar em metodologias aplicadas ao ensino musical da diáspora africana. Nzewi advoga uma teoria profunda sobre as artes musicais africanas que não exclui os saberes ocidentais, mas deixa claro que o ponto de partida, teriam que ser os saberes dos detentores dos saberes originais nas culturas africanas.

\section{In-Conclusões}

O presente trabalho se propôs a contextualizar as artes musicais da diáspora africana na perspectiva multidisciplinar e na busca de novas epistemologias para uma educação musical que possa assumir as bases musicológicas e filosóficas das artes musicais africanas e das que surgiram no complexo cultural e histórico do Atlântico Negro. Isso não significa reduzir o debate transcultural exclusivamente às músicas de matrizes africanas e sim, incluir as músicas indígenas, assim como as de origem europeia, nas suas diversas matrizes da tradição oral que foram determinantes para muitas formas musicais e performáticas da América Latina, mas que neste momento não foram aprofundadas, porque requerem estudos e contextos específicos que precisariam serem incluídos numa formação musical "afro-ameríndia-latina". Também não foi possível de incluir as demais dimensões e debates contemporâneos sobre globalização, descolonização, diversidade e identidade cultural, sobre novas tecnologias e mídias que conferem novos aspectos, saberes e contextos ao fazer musical, consequentemente aos processos de criação, recepção e educação musical, para uma formação musical profissional "num mundo modificado" (KOELLREUTER, 1977). Além disso, faz-se necessário de contemplar os movimentos sociais, migratórios e debates políticos emergentes que coloquem as culturas pós-modernas em contextos transnacionais por toda parte do mundo. $O$ objetivo aqui não é reduzir um debate muito mais amplo em torno de uma educação musical das músicas do mundo, como tem sido objeto de muitas pesquisas e publicações internacionais nos últimos anos, para uma problematização que seria somente afro-latina, e sim, recuperar uma temática que pouco se fez presente no corpo teórico e curricular do ensino musical universitário na América Latina. Somente quando criamos

\footnotetext{
19

One stance that is evident throughout Nzewi's work is a profound mistrust of non-Africa-centred views. (Please note that 'non-Africa-centred' is not the same as 'non-African'.) This is a complex position that has undergone redefinition in the course of many writings, and will no doubt continue to be modified with the accumulation of new contexts and experiences in coming years. Nzewi's rejection of non-Africa-centred views is not reducible to a banal us-versus-them dichotomy; nor is it one of those let-us-study-ourselves positions. It is not a culture-bearercan-do-no-wrong kind of view; it is not a crude embrace of blackness and a principled resistance to whiteness. Indeed, Nzewi is equally critical of African and non-African writers. He is critical of those African writers who accept unquestionably a Western epistemological framework, as well as those non-Africans who refuse to be instructed by indigenous African perspectives and who insist on imposing Western categories on African music. His positions stem from a belief - hardly controversial - that a prerequisite for writing about a musical culture is that the researcher knows that culture from the inside, from the perspectives made available by culture bearers.
} 
de fato parâmetros para o estudo teórico e prático das músicas afro-latinas nos cursos de graduação e pós-graduação da América Latina, podemos nos projetar no campo dos estudos transculturais de música no âmbito internacional. Para alcançar esse objetivo, torna-se necessário de aprofundar estudos e leituras de uma vasta bibliografia que não se alimenta de uma vertente acadêmica fechada em si, como temos visto por demais ainda hoje, no sec. XXI, em muitas faculdades que não dialogam entre si, como resultado de uma visão cartesiana, patriarcal, elitista e excludente que durante séculos, pouco abriu espaços para pensar, estruturar e religar de forma horizontal, rizomática, dialógica, inclusiva, construtiva, transcendental e sensorial-corporal. Um primeiro passo nessa direção, encontra-se em Makl, e outros, que apontam os pilares das músicas performáticas das diásporas africanas:

\begin{abstract}
Para entender essas práticas musicais, precisamos atender suas formas de organização, sua feitura em performance. Precisamos ir além da língua como analogia de práticas significantes, evitando assim que a textualidade nos impeça a compreensão da totalidade; precisamos colocar em foco às performances, enquanto elas são irreduzíveis à textualidade das palavras. O foco das performances dá conta do sentido que a música tem a respeito das identidades sociais, bem como ela é experimentada, reproduzida e inventada das maneiras mais intensas por meio do movimento corporal, da mímica, dos gestos. (MAKL, 2011, p. 62)
\end{abstract}

Portanto, urge construir novos ou incluir antigos parâmetros e paradigmas estéticos em diálogo, gerando uma contemporaneidade latino-americana, que vai muito além do que a concepção tradicionalista nas Escolas de Artes da América Latina, que funcionam ainda em parte como apêndice da antiga burguesia europeia. Nem mesmo na Europa no campo das artes musicais e performáticas, as epistemologias, fundamentos e práticas seguem essa visão histórica e estreita sobre as artes, que foi o ideal classicista durante séculos. As artes musicais e cênicas africanas, indígenas e asiáticas, assim como as próprias tradições orais e populares europeias, esquecidas durante décadas, hoje fazem parte do repertório das criações e vivências artísticas em muitas universidades europeias e norte-americanos.

Nesse artigo dei voz propositalmente para muitos/as escritores/as de contextos acadêmicos, lugares e tempos diferentes de países africanos e da diáspora africana, para aproximar os/as leitores/as, à diversidade e complexidade de publicações internacionais, os quais somente representam uma pequena seleção de autores/as, temas e abordagens possíveis. Tenho consciência de que a maioria desses/as autores/as não se encontra nas referências curriculares e bibliotecas das formações musicais universitários da América Latina. Portanto, faço um apelo para que os/as pesquisadores musicais se inspirem nessas publicações, e abordagens, e vão além, na busca de mais referências e experiências musicais que acontecem diariamente no nosso continente. 


\section{Bibliografia}

AGAWU, Kofi. „The communal ethos in African performance: ritual, narrative and music among the northern ewe." Em Trans - Revista Transcultural de Música, no. 11, 2007, p. 1-11.

AGAWU, Kofi. „Meki Nzewi and the discourse of African musicology: a 70th birthday appreciation", em Journal of Musical Arts in Africa, vol 5, p. 1-18, 2008.

ALMEIDA, Berenice e PUCCI, Magda Dourado. Outras terras, outros sons. São Paulo: Callis Editora, 2015. 3. Ed.

AUSTERLITZ, Paul. Jazz consciousness. Music, race and humanity. Middletown: Wesleyan University Press, 2005.

BARATA, Denise. Samba e Partido Alto: As Curimbas do Rio de Janeiro. Rio de Janeiro: EDUERJ, 2011.

BEBEY, Francis. African Music. A people's art. New York, Laurence Hill Books, 1975.

BEHAGUE, Gerard. (edit.) Music and Black Ethnicity. Miami: North-South Center Press of University of Miami, 1992.

“Rap, Reggae, Rock, or Samba: The Local and the Global in Brazilian Popular Music (1985-95)." Em Latin American Music Review / Revista de Música Latinoamericana, Vol. 27, No. 1 (Spring - Summer, 2006), pp. 79-90

BERENDT, J. E.; HUESMANN, G. O livro do Jazz. De New Orleans ao século XX. São Paulo: Perspectiva: Edições SESC, 2014.

DORING, Katharina. "Uma escola de música e artes brasileiras na Bahia". em Revista da FAEEBA: Educação e Contemporaneidade. Salvador, v. 15, n. 25, p. 173-184, jan./jun., 2006.

. "Ouvindo a diversidade musical do mundo: para uma educação musical cognitiva "além das fronteiras". Em Revista da FAEEBA: Educação e Contemporaneidade. Salvador, v. 26, n. 48, p. 27-46, jan./abr. 2017

DU BOIS, W. E. B. The Souls of Black Folk. New York: Penguin Books, 1989.

FLOYD Jr., Samuel A. The Power of Black Music: Interpreting Its History from Africa to the United States. New York: Oxford University Press, 1995. 
FLOYD Jr., Samual A.; ZECK, Melanie; RAMSEY, Guthrie. The Transformation of Black Music: The Rhythms, the Songs, and the Ships of the African Diaspora. New York: Oxford University Press, 2017.

HERBST, Anri (org.). Emerging solutions for musical arts education in Africa. Capetown: PASMAE - African Minds, 2005.

HOBSBAWM, Eric. História social do Jazz. Rio de Janeiro: Paz e Terra, 1990.

JONES, Leroi (Amiri Baraka). Black Music. New York: AkashiClassics, 2010.

KOELLREUTTER, H. J. "O ensino da Música num mundo modificado". Em Cadernos de Estudo Educação Musical, UFMG, v. 6, p. 43-44, 1997.

KUBICK, Gerard. Africa and the Blues. Jackson: University Press of Mississippi, 1999.

LARKIN Nascimento, Elisa (org.). A matriz africana no mundo. Série Sankofa: Matrizes africanas da cultura brasileira. São Paulo: Selo Negro, 2008.

LIMA, Ari. "Do samba carioca e industrial ao samba nacional e mestiço." Em ArtCultura, Uberlândia, v. 15, n. 26, p. 121-135, jan.-jun. 2013.

LÜHNING, Ângela. "Sustentabilidade de patrimônios musicais e políticas públicas a partir de experiências e vivências musicais em bairros populares." em Música e Cultura: Revista da ABET, vol. 8, n. 1, 2013, p. 44-58

MAKL, Luís Ferreira. "Música, artes performáticas y el campo de las relaciones raciales." Área de estudios de la presencia africana en américa latina. En Los estudios afroamericanos y africanos en América Latina. Cordoba: CEA-CLACSO, 2008, p. 225-250.

"Artes musicais na Diáspora Africana. Improvisação, chamada-e-resposta e tempo espiralar." Em Outra Travessa no. 11, PPGL - UFSC, 2011.

MALOMALO, Bas'ilele. Repensar o multiculturalismo e o desenvolvimento no Brasil: políticas públicas de ações afirmativas para a população negra (1995-2009): vol. 1. Porto Alegre: Editora Fi, 2017.

MANUEL, Peter. Carribean Currents. Filadelphia: Temple University Press, 1995.

MOORE, Robin. "Música negra e a diáspora: Reflexões sobre o caribe hispânico." Em Projeto História, São Paulo, n. 44, 2012, pp. 305-319. 
NKETIA, Kwabena. "Cultural Diversity and Music Education in Ghana" em TRAASDAHL, J. O. (ed.). Music Education in a Multicultural Society. Copenhagen: Danish Music Council, 1999, p. 50-59.

NZEWI, Meki. "Reinstating the soft science of african indigenous musical arts for humanity sensed contemporary education and practice", em Revista da FAEEBA, Educação e Contemporaneidade, Salvador, v. 26, n. 48, 2017, p. 61-78.

NZEWI, Meki; Omolo-Ongati, Rose. "Injecting the african spirit of humanity into teaching, learning and assessment of musical arts in the modern classroom." Em Journal of the musical arts in Africa. Vol, 11, 2014, p. 55-72.

OLIVEIRA, Eduardo. "Filosofia da ancestralidade como filosofia africana: educação e cultura afro-brasileira." Em Revista Sul-Americana de Filosofia e Educação, No. 18, 2012, p. 28-47.

REID, George Andrews. América Afro-latina, 1800-2000. São Carlos, EdUFSCar, 2007.

SANSONE, Lívio e SANTOS, Jocélio Teles dos. Ritmos em trânsito, Sócio-antropologia da Música na Bahia. São Paulo: Dynamis, 1998.

SCHIPPERS, Huib. Facing the Music. Shaping music education from o global perspective. New York: Oxford University Press, 2010.

SIDRAN, Black Talk. Schwarze Musik - die andere Kultur im weissen Amerika. Hofheim: Wolke Verlag, 1985.

SMALL, Christopher. Music of the Common Tongue - Survival and Celebration in African American Music. Middletown: Wesleyan. University Press, 1998 (1987).

Musicking. The meanings of performing and listening. Middletown: Wesleyan. University Press, 1998.

STORM, Robert. Black Music of two worlds. New York: Schirmer Books, 1998.

WHITTEN, Norman; TORRES, Arlene. Blackness in Latin America and the Caribbean. Vol. I \& II. Bloomington: Indiana University Press, 1998. 